\title{
非線形弾性要素を有するアクチュエータ（ANLES）を 用いた拮抗駆動型関節の剛性および姿勢制御
}

\author{
山下裕* 小金澤 鋼 一*
}

\section{Stiffness Control of Antagonistically Driven Joints Mechanism}

Hiroshi Yamashita* and Koichi Koganezawa*

\begin{abstract}
The paper presents a three DOF mechanical wrist that is capable to control its joint stiffness as well as joint angle by using the ANLES (Actuator with Non-Linear Elastic System). First it describes the structure of the ANLES followed by the designing method of the non-linear elasticity. Subsequently it shows the second machine of the wrist joint controlled by the ANLES of which size and weight are downsized nearly a half compared to the first machine. Next it presents a new ANLES (we call V-ANLES) that has a viscosity to suppress vibrations caused by the elasticity. It follows the experimental results of the step-response of the joint to show the V-ANLES successfully diminishes the overshoot. Finally it shows the experimental results to rotate the wrist joint about Z-axis by using the four ANLES.
\end{abstract}

Key Words: Antagonistic Driving, Stiffness Control, Nonlinear Elasticity

\section{1. 緒}

ヒトとロボットが一体となって協調作業を行う世の中はそう 遠くない. 現在, パワーアシストスーツや自動車の ABS 機能な どは，直接，間接的にヒトと協調して動作するものであり，人 間の動きを感知して所要のアウトプットを行う。今後, これら マンマシン・システムがさらに発展するためにはその本質的安 全性が重要になり, フィードバック制御に過度に頼ることのな い, 外界への柔軟性が求められる.

人間の巧みな動きは, 関節の姿勢, 剛性を自由に操作するこ とによって実現している，人間の笳骨格系は関節剛性を調整す る能力をもっており, その中心となる機構は筋骨格系の拮抗筋 構造である [1]. 関節には運動に協同して動く筋肉, 協同筋群 (agonist) と運動に抵抗して動く筋肉, 拮抗筋群（antagonist） が対に設置されている，両方の筋の緊張が強い場合高い関節剛 性を与え弱い場合低い関節剛性を与える。ここで注意すべき点 は，関節剛性はオープンループで設定されるということである. すなわち外力が作用する前に関節剛性はあらかじめ設定されて いる。ここで言う関節剛性とは外力に対する関節の動きやすさ, 難しさの度合いを示すものであり, 回転関節では単位角度動か すために必要なトルクで表すことができ, 次式で定義される。

$$
S=\partial \tau / \partial \theta
$$

原稿受付 2010 年 4 月 30 日

*東海大学工学部機械工学科

* Department of Mechanical Engineering, Tokai University

ロ 本論文は有用性で評価されました。

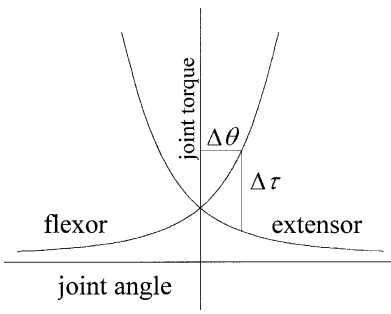

(a) Low stretching

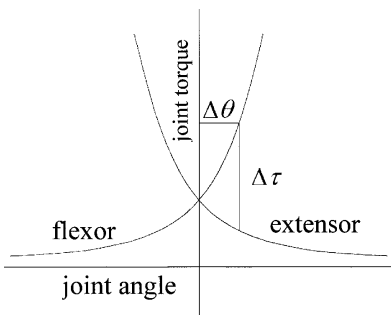

(b) High stretching
Fig. 1 Stiffness regulation of antagonistically driven joint

Fig. 1 は拮抗する二つの筋（Flexor, Extensor）の筋張力に より関節に発生するトルクの静的なつりあい状態を示している. この状態から外トルク $\Delta \tau$ が関節に作用したとき関節が $\Delta \theta$ だ け回転するとしている。図の曲線のような非線形弾性特性を有 する弾性体を想定した場合，同じ関節角度を $\Delta \theta$ だけ変化させ るとき, 関節卜ルクの平衡点が低い場合 (Fig. 1 (a)）に比べ関 節トルクの平衡点が高い場合 (Fig. 1(b)) のほうが $\Delta \theta$ 変化し たとき関節が元に戻ろうとするトルク $\Delta \tau$ の值が大きく式 (1) より剛性が増加していることが分かる。このことから拮抗筋形 駆動関節において非線形弾性体を拮抗させて用いることで剛性 を変化させることができる．多くの運動生理学上の研究による と，人間の筋は剛性を調整するために, Fig. 1 に示すような非 線形弾性特性を持っていることが明らかになっている [2]〜 [4].

これまでいくつかの研究に扔いて剛性調節を可能とする駆動 機構が提案されている，高卜ルクや，俊敏な姿勢制御が可能な 
機構, 高弾性など様々な利点を有しており, それらは機構上剛 性を変化させることができ, 接触時の瞬時の対応を可能として いる $[5] \sim[7]$.

また，制御により仮想的コンプライアンスを実現する試みも 行われており, 細かな位置決めや要求した剛性を瞬時に出すこ とが可能である [8] [9]. また, 高分子材料を使用したアクチュ エータは小型であること, エネルギーロスが少ない等で注目さ れている [10].

しかし, 固有な非線形特性を持つ弾性体を用いる場合, その弾 性特性を仕様の関節剛性に合わせて設計することが困難である. また，仮想コンプライアンス制御は以下の点で問題点がある.

(1)多自由度系の制御における計算処理負荷

(2)応答性

(3)安定性, 安全性

そこで, 本論文では, 先行研究 [11] で提案した非線形弾性要 素（Non-Linear Elastic Module 以下，NLEM）を有するアク チュエータ (Actuator with Non-Linear Elastic System, 以 下 ANLES）を用い人間と同等の大きさの 3 自由度手首関節を 製作, 姿勢制御実験, 剛性制御実験を行い, ANLES およびそ れを用いた 3 自由度手首関節の有用性を示す．また， 1 号機， 2 号機の Z 軸姿勢制御は，主軸モー夕を使用し制御を行っている が, ANLES を個別に動かすことによって制御することを提案 し，実機での検証結果について報告する.

最後に, ANLESがバネ・マス系で構成されているため振動を 発生してしまう問題を解決するため粘性要素を加えた ViscousANLES を提案し, 実機での検証結果について報告する.

\section{ANLES}

\subsection{ANLES の設計手法}

ANLES は NLEM (Non-Linear Elastic Module), ボール ネジ，ユニバーサルジョイント，から構成されている．NLEM は, ガイドシャフト, ネジリコイルバネ, 伝達盤等から構成さ れる（Fig. $2(\mathrm{a})$ )。 ガイドシャフトの外側にネジリコイルバネ が巻かれており, バネは, ガイドシャフトとボールネジナット に一端が固定されており，もう一端は，伝達盤に接続されてい る。バネの外側にはバネのたわみを防止するためのガイドブッ シュが取り付けられている（Fig. $2(\mathrm{a})$ ). ボールネジは, 回転 と直動を効率よく相方向に変換するため超大リードボールネジ ロッド（直径 $6[\mathrm{~mm}]$, リード $5[\mathrm{~mm}]$ ）を採用している. ガイ ドーシャフトの外径は Fig. 2 (a) に示すようになだらかに変化 するように設計される.

モータからの回転により, ガイドシャフトとバネが回転し, こ のときバネは一端が伝達盤に固定されているため, ねじれる。ネ ジリコイルバネは，ねじれるほどにその内径が小さくなるため， ガイドシャフトの外径の大きいほうから巻きついていく．した がって巻かれるに従いバネの有効長さが短くなり機構上のバネ 定数は増加していく.

Fig. 3 はガイドシャフトの左端から軸方向に $x$ の距離までバ ネがガイドシャフトに巻きついている状態を示している。 バネ が巻角 $\phi$ まで巻きついたときの，巻きつき展開長さを $l_{a}$ とす ると,

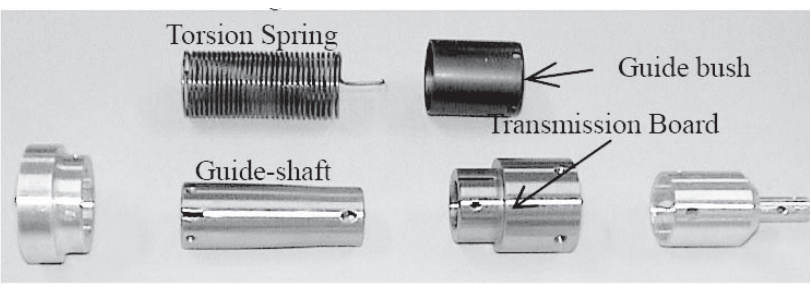

(a) Parts of NLEM

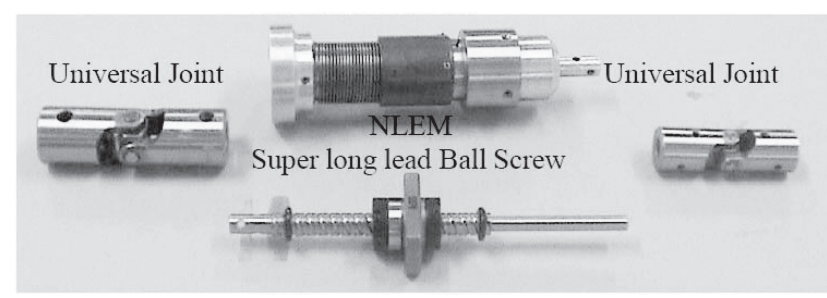

(b) Parts of ANLES

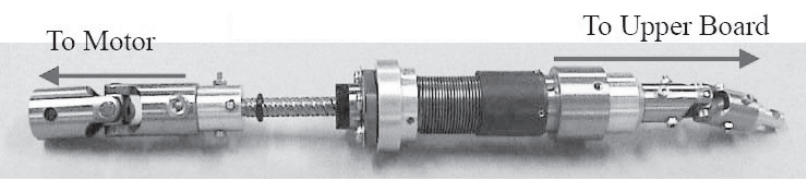

(c) ANLES whole view

Fig. 2 Part and the assembling of ANLES

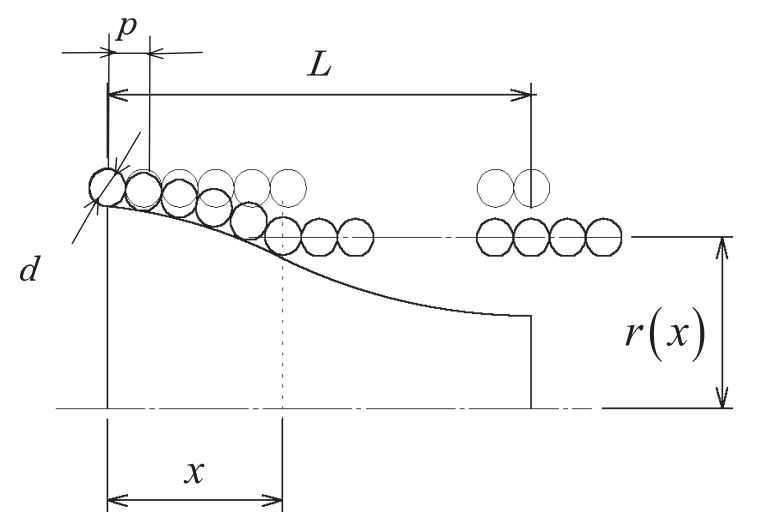

Fig. 3 The state of torsion spring not coiled on the guide-shaft

$$
l_{a}(x)=\int_{0}^{x} \sqrt{(r(x) d \phi)^{2}+\left(\frac{p}{2 \pi} d \phi\right)^{2}}
$$

となる.ここで, $r(x)$ は案内軸の軸方向距離 $x$ における案内軸 の半径にバネ線形の $1 / 2$ を加えた長さである (Fig. 3 参照). $p$ はピッチである。巻きついていない展開長さ $l_{b}$ は

$$
l_{b}(x)=\frac{L-x}{p} \sqrt{(2 \pi r(x))^{2}+p^{2}}
$$

$L$ は案内軸の軸方向長さである。これらにより巻きつくことに よって軸方向に伸びた部分のバネの全展開長さ $\Delta l$ は, 展開長 さを $l$ として

$$
\Delta l(x)=l-l_{a}(x)-l_{b}(x)
$$

この $\Delta l(x)$ よりプーリの回転角 $\phi$ は

$$
\phi(x)=\Delta l(x) / r(x)
$$




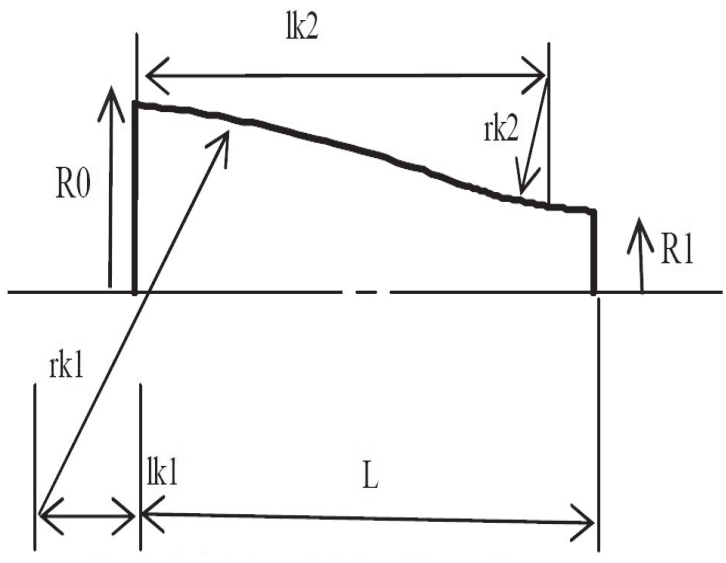

Fig. 4 Definition of design Parameters

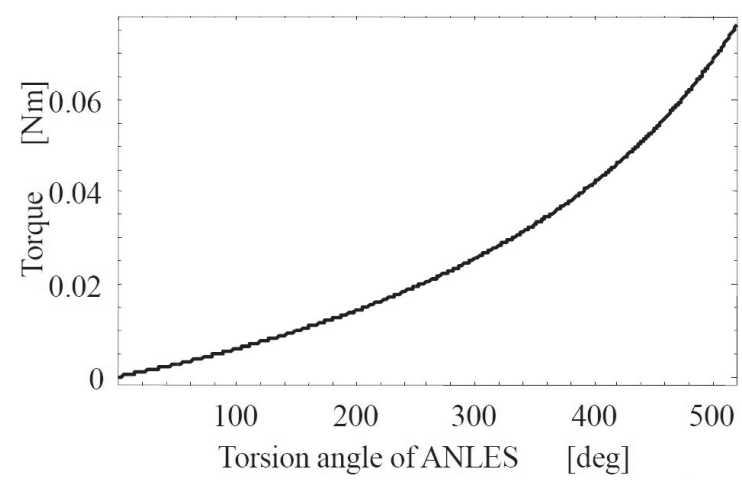

Fig. 5 Non-linear elasticity of the ANLES designed according to the parameters shown in Table 1

で得られる。 バネの有効展開長さ $l_{r}(x)$ は

$$
l_{r}(x)=l-l_{a}(x)=l_{b}(x)+\Delta l(x)
$$

$x$ まで巻きついた状態からさらに $\Delta \phi$ だけ巻くために必要なト ルク $\Delta T_{g}(x)$ は， $E$ をバネのヤング率, $I$ を断面二次モーメン トとすると

$$
\Delta T_{g}(x)=\left(E I / l_{r}(x)\right) \Delta \phi
$$

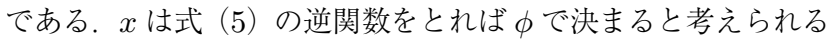
ので式（7）は,

$$
\Delta T_{g}(\phi)=\left(E I / l_{r}(\phi)\right) \Delta \phi
$$

とできる。ゆえにバネ定数 $k(\phi)$ は

$$
k(\phi)=E I / l_{r}(\phi)
$$

このことからバネ定数は巻き角 $\phi$ の非線形関数となる. 以上 より $l_{r}$ はガイドシャフト半径 $r(x)$ の設計により決まるので非 線形弾性特性を自由に設計できる.

Fig. 4 にガイドシャフト外径の設計パラメータを示す.ここ では二つの円弧がなだらかに接続する形状を採用している。 Table 1 に示した設計值により製作したガイドシャフト（Fig. 2 (a)） の巻角 $\phi$ に対するトルクの理論值を Fig. 5 に示す.
Table 1 Designed value of the parameters

\begin{tabular}{|l|c|r|}
\hline $\begin{array}{l}\text { Horizontal position of the center of } \\
\text { the first curvature }\end{array}$ & $\mathrm{lk} 1$ & $\begin{array}{r}-8.87 \\
\mathrm{~mm}\end{array}$ \\
\hline $\begin{array}{l}\text { Horizontal position of the center of } \\
\text { the second curvature }\end{array}$ & $\mathrm{lk} 2$ & $21.6 \mathrm{~mm}$ \\
\hline Radius of the first curvature & $\mathrm{rk} 1$ & $359 \mathrm{~mm}$ \\
\hline Radius of the second curvature & $\mathrm{rk} 2$ & $320 \mathrm{~mm}$ \\
\hline Diameter of the spring wire & $\mathrm{d}$ & $0.8 \mathrm{~mm}$ \\
\hline Pitch of the spring & $\mathrm{p}$ & $1.0 \mathrm{~mm}$ \\
\hline Winding number of the spring & $\mathrm{n}$ & 24 \\
\hline Maximum radius of the guide shaft & $\mathrm{R} 0$ & $8 \mathrm{~mm}$ \\
\hline Minimum radius of the guide shaft & $\mathrm{R} 1$ & $7 \mathrm{~mm}$ \\
\hline Length of the guide shaft & $\mathrm{L}$ & $24 \mathrm{~mm}$ \\
\hline
\end{tabular}

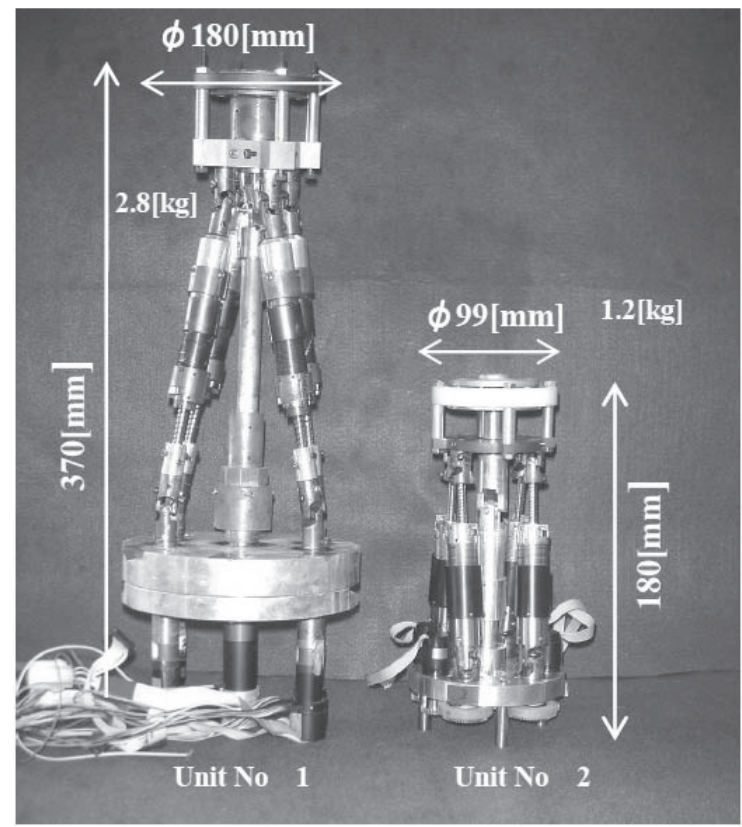

Fig. 6 Appearance of the wrist joints; Unit No.1 and No.2

\section{3. 拮抗駆動型手首関節}

前章で述べた ANLES を用い，人間の手首のような 3 自由度 を有し，さらに関節剛性を調節できる拮抗駆動型手首関節のメ カニズムを提案する.

本研究は 3 自由度手首関節の試作 1 号機（Unit No.1）を開 発し（Fig. 6)，基本性能を確認したあと，各部の改良ならびに 重量, サイズの大幅な縮小を目指した 2 号機（Unit No.2）を 製作した. Fig. 6 に 1 号機と 2 号機の概観を示す. 2 号機は 1 号機に対し，サイズおよび重量でほぼ半減を実現し，人間の前 腕にほぼ収まるほどのものとなった。

Fig. 7 に 2 号機の構造を示す。パーツの構成は, 手首根元か ら，モー夕部，下板部，主関節部，上板部，そして遊星歯車部と なっている。モータは，各 ANLES に一つ，主軸に一つ接続さ 


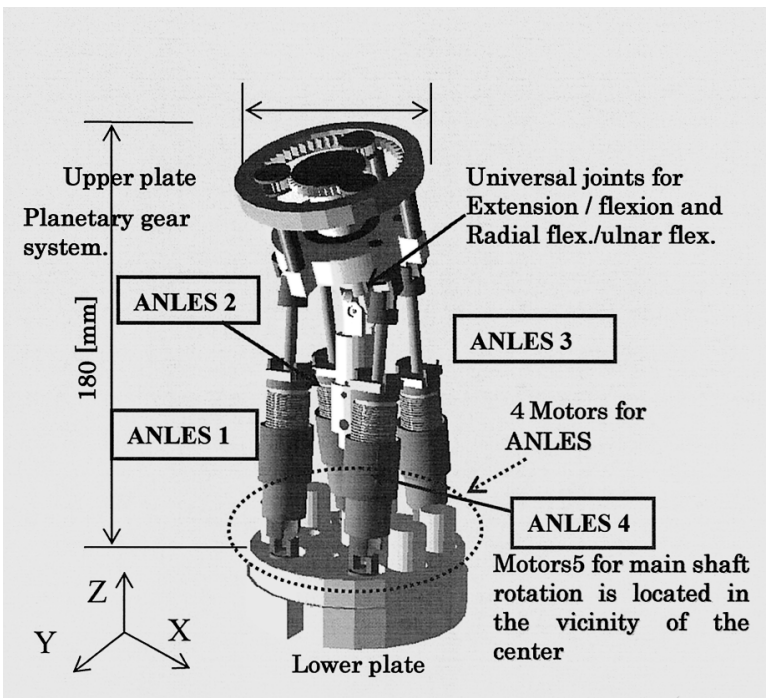

Fig. 7 Structure of 3.D.O.F. Wrist Joint (Unit No.2)

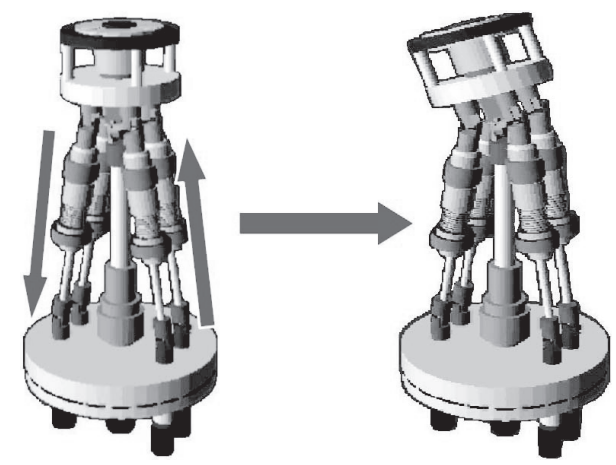

Fig. 8 3.D.O.F. joint angle control

れており合計五つ使用している。また，ANLES とモータ，また 上板の接続部にユニバーサルジョイントを用いた。 そうするこ とで，手首関節の姿勢変化に対し回転を妨げられずに ANLES に伝えられるようにしている。

\section{1 関節の駆動}

拮抗して配置しているANLES をモータで互いに逆方向に 回転させることにより, ボールネジが直動し, 手首の背屈一掌 屈 (以降 $\mathrm{X}$ 軸回転), 橈屈一尺屈 (以降 $\mathrm{Y}$ 軸回転) の姿勢制御 を行う。これら 2 自由度の回転を複合させることも可能である (Fig. 8). また手首の回内一回外（以降 Z 軸回転）は, 主関節 下方に直接接続されているモー夕 5 を回転させ, モー夕の回転 が主関節, 太陽歯車と伝えられ遊星歯車を公転させ, 遊星歯車 に固定されているキャリアが回転し，その先の手先が Z 軸方向 に回転する機構になっている（Fig. 9)。また， 5.3 節で示すよ うにモータ 5 で駆動するのではなく 4 本の ANLES の駆動によ り \pm 20 度程度の $\mathrm{Z}$ 軸回転が可能である。

\section{2 関節角度の計測}

関節角度を計測するために主軸の 2 軸関節として独自のユニ バーサルジョイントを開発した。このダイス部において, 半円 形状をしたカムが関節の $\mathrm{X}$ 軸， $\mathrm{Y}$ 軸まわりに配置されている (Fig. 10).このカムの回転中心が関節の回転軸から少しずれ

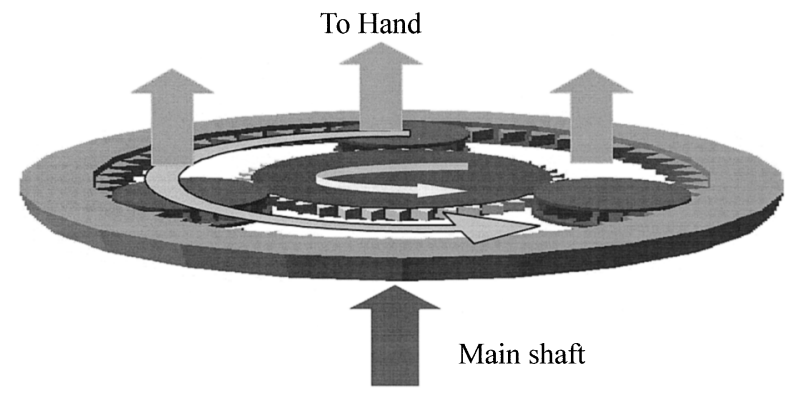

Fig. 9 Activerotation of Z-axis via the planetary gearsystem

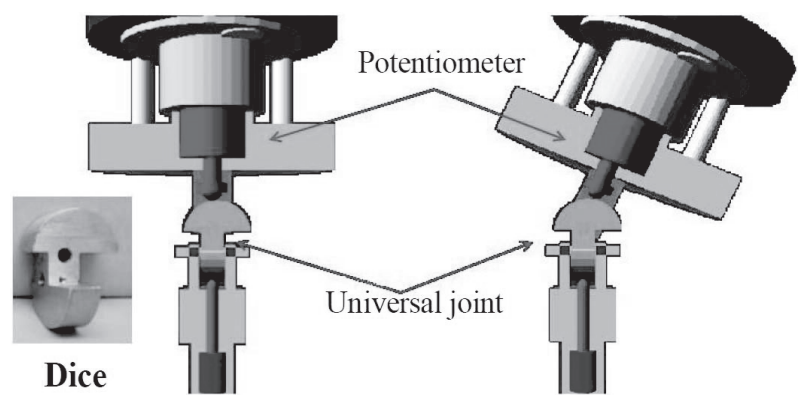

Fig. 10 2.D.O.F. joint angle sensing system equipped in the universal joint

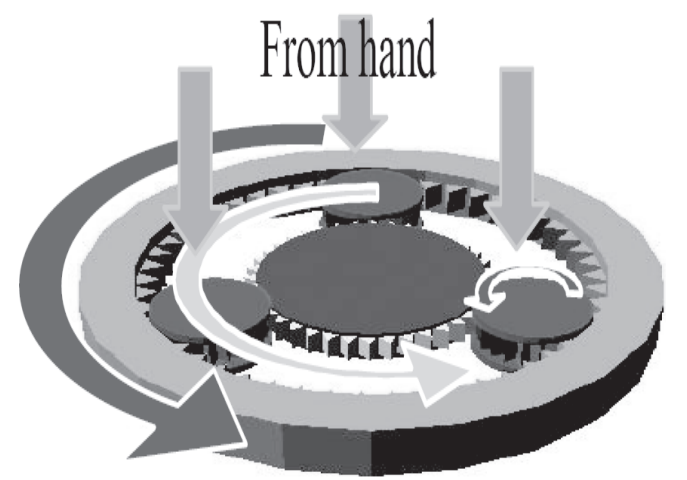

Fig. 11 Passive rotation of Z-axis via the planetary gear

た位置にある。関節の $\mathrm{X}$ 軸， $\mathrm{Y}$ 軸まわりの回転がカムに接触し ているプローブにより直動に変換されポテンショメータにより 回転角度を検知する構造になっている（Fig. 10）。この角度計測 機能付きユニバーサルジョイントを用いることにより。主軸の 外部に角度センサを配置する必要がなくなる。

\section{3 剛性制御}

剛性制御は四つの ANLES により行う。各ANLES をモータ で同方向に回転し，初期巻角を与えることで手首関節の 3 軸の 剛性が決まる。本来 3 軸を制御するには 6 本の ANLES が必要 であるが, 本機構で腱の役割の ANLES を 4 本にし，Z 軸の姿 勢制御は主にモー夕 5 により行う機構とした。したがってX． $\mathrm{Y}$ 軸周りの剛性制御はある程度独立して制御することが可能だ が， Z 軸周りの剛性值は，XY 軸の剛性に対して独立していな い. 手先から外力が加わると, 主軸のモータが回転しないため, キャリアから内歯車に回転が伝わる（Fig. 11），そのため内歯 車の回転により ANLES の軸がFig. 12 に示すように傾き，軸 長が伸びるため ANLESがねじられる。したがって，ANLES 

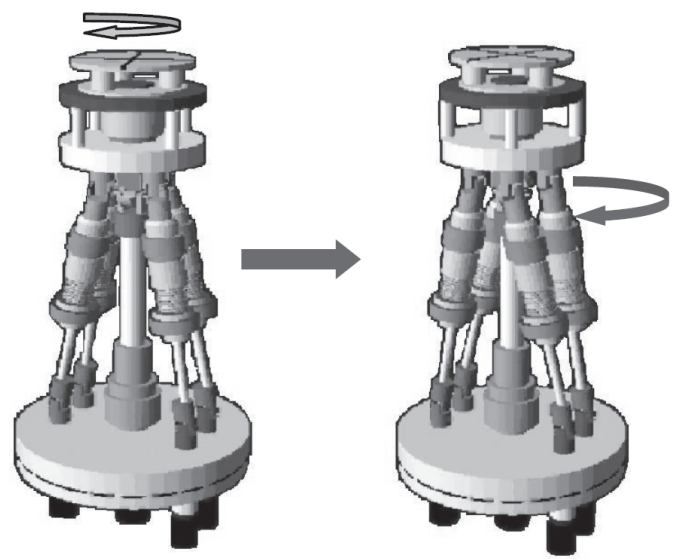

Fig. 12 Twisting of ANLES when the carrier is externally rotated

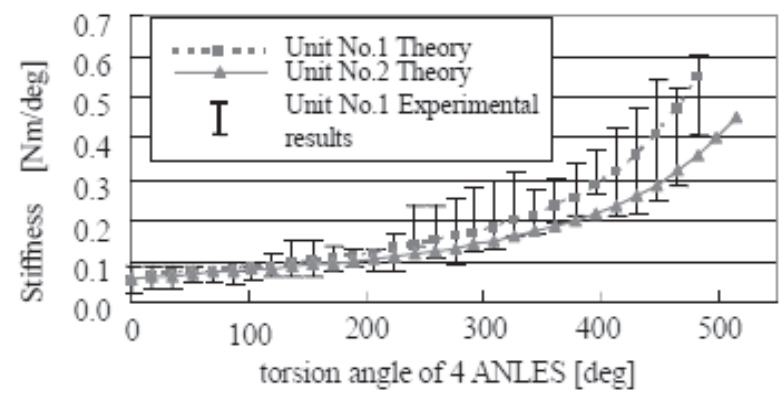

(a) Experimental results of measuring stiffness of the $\mathrm{X}$-axis

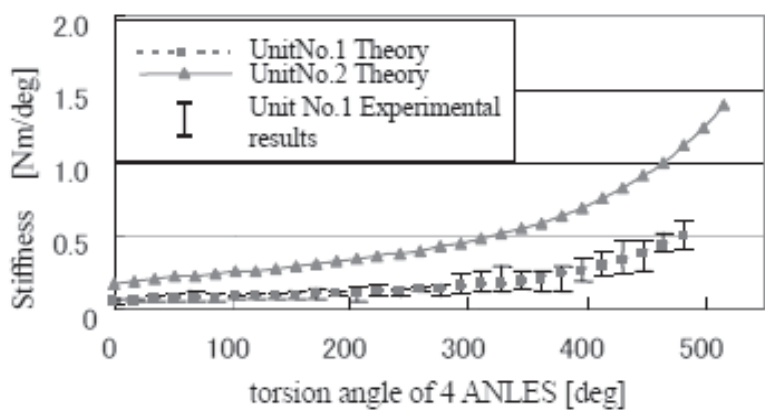

(b) Experimental results of measuring stiffness of the Y-axis

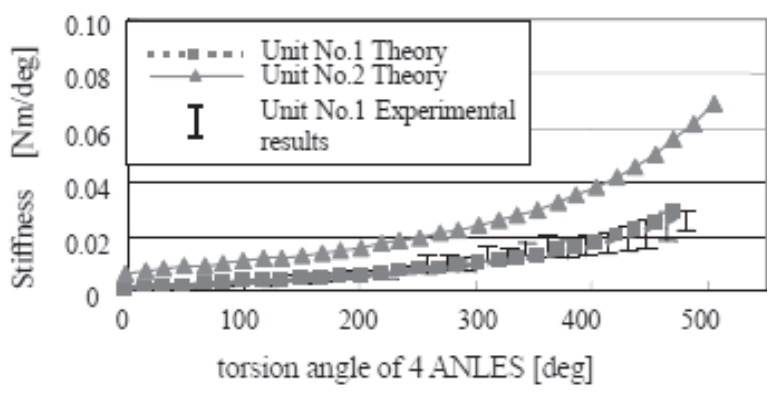

(c) Experimental results of measuring stiffness of the Z-axis

Fig. 13 Experiment results of the joint stiffness control under constant joint angle (Unit No.1) with the theoretical curve of the Unit No.2

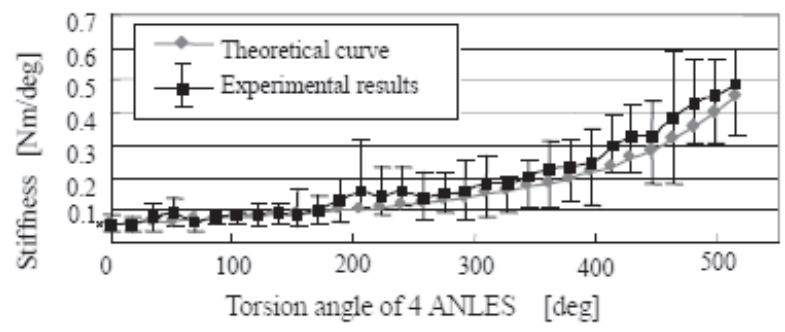

(a) Experimental results of the stiffness of the $\mathrm{X}$-axis joint

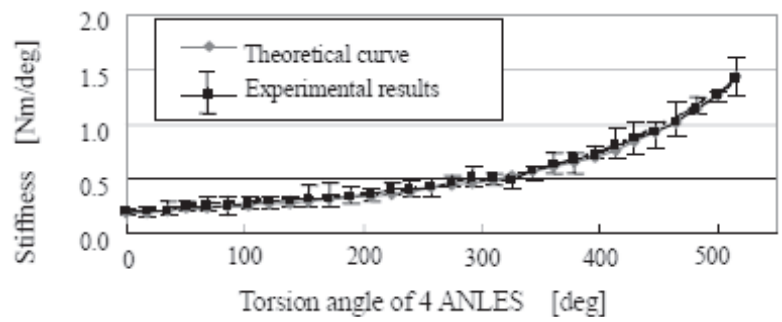

(b) Experimental results of the stiffness of the $\mathrm{Y}$-axis joint

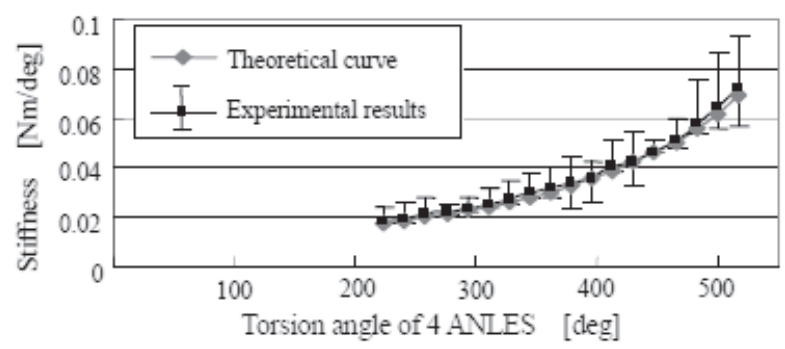

(c) Experimental results of the stiffness of the Z-axis joint

Fig. 14 Experiment results of the joint stiffness control under constant joint angle (Unit No.2)

の初期巻角より Z 軸の剛性が決まることになる。したがってこ の機構では，Z 軸の剛性だけを調節することはできず，Z 軸の剛 性值を高めたい場合には XY 軸の剛性值も同時に高めなければ ならない，人間の手首関節に扔いても日常動作に㧍いて手首の 3 軸の剛性值はほぼ一体として調節されており [12], この機構 においても再現できる手首の功緻的動作は多いと考える。むし ろ外界からの未知な方向からのコンタクトを想定した場合, 全 方向の関節剛性值を大きく，あるいは小さく調節するほうが有 利である。

\section{2 号機 3DOF 手首関節}

Fig. 13 は 1 号機の剛性制御実験結果と比較のため 2 号機の 理論值を示している．㴊性の測定方法については次章に記す。ま た関節剛性と関節角度を独立して制御するための理論式につい ては文献 [11] を参照されたし．エラーバーは 5 回の繰り返し実 験結果ばらつきを示している。1 号機の実験結果は, 理論值と 実験值がほぼ一致しており理論通り剛性制御が可能であること が分かる。手首関節 2 号機の Y 軸および Z 軸の剛性理論值は, Fig. 13 に示すように 1 号機に比べ約 2 倍になるように設計し た。これは，ANLES のバネを強くしたこと，Y 軸および Z 軸 方向に回転が生じたときに，より大きく ANLES の張力方向に 変移が生じるように ANLES の配置を変更したことによる。し かし，配置の影響で X 軸の剛性は減少した。 


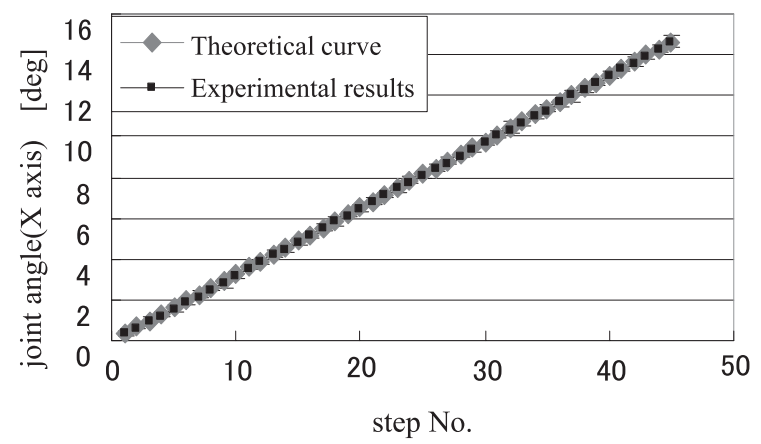

(a) Experimental results of X-axis joint angle

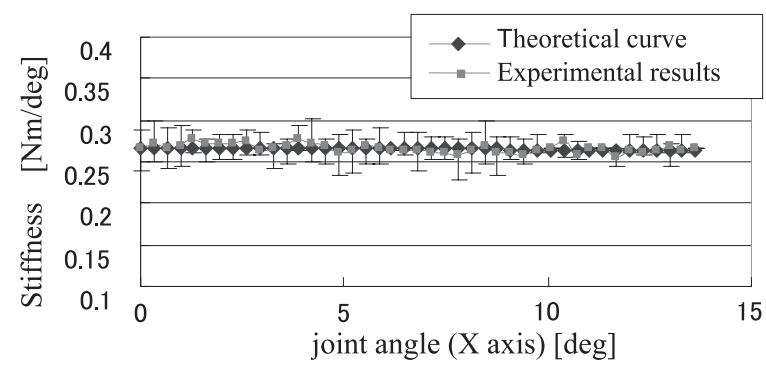

(b) Experimental results of the stiffness of $\mathrm{X}$-axis joint

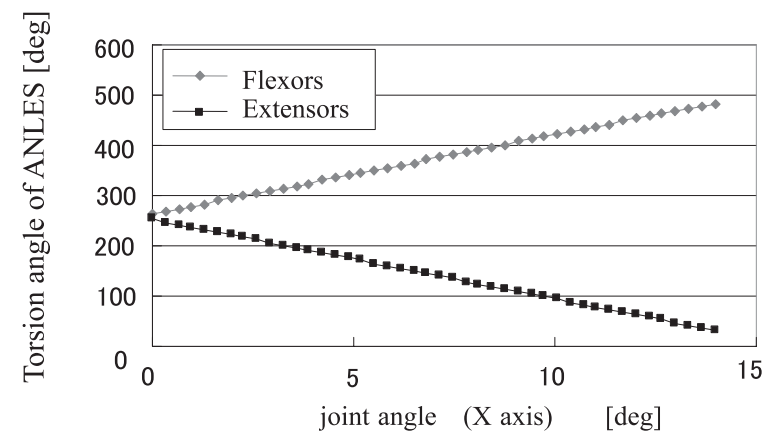

(c) Assigned torsion angle of ANLES to rotate the joint (X-axis)

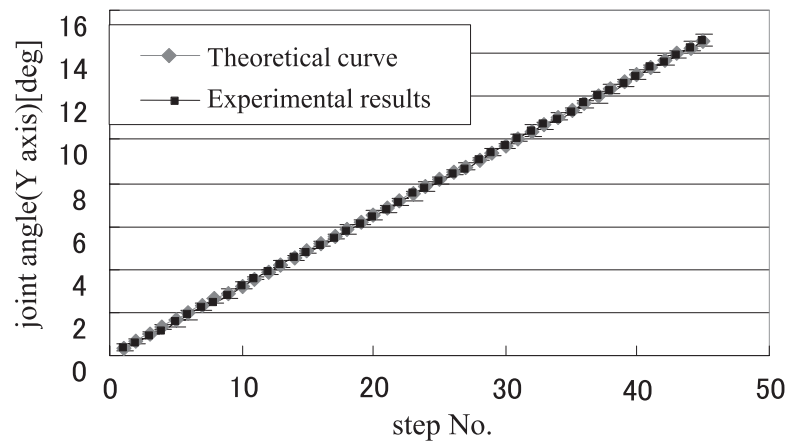

(d) Experimental results of Y-axis joint angle

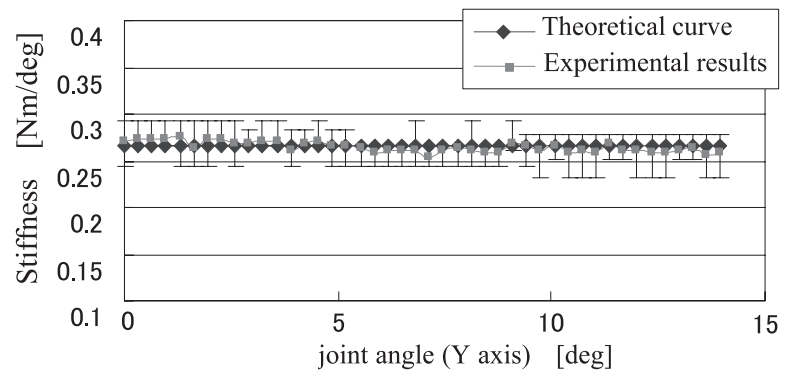

(e) Experimental results of the stiffness of Y-axis joint

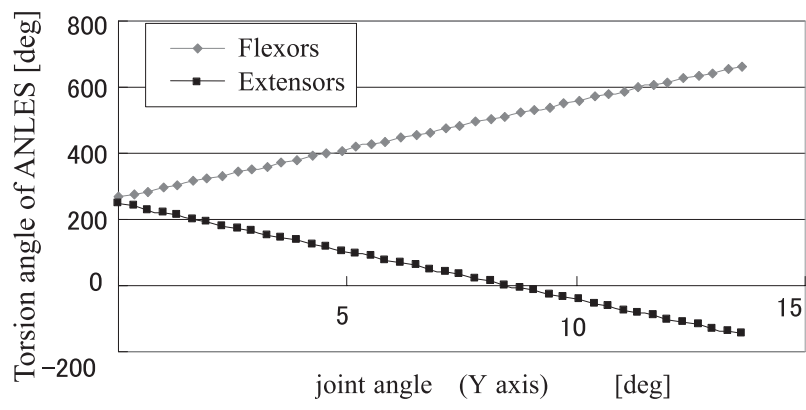

(f) Assigned torsion angle of ANLES to rotate the joint (Y-axis)

Fig. 15 Experimental results of the joint angle control under constant joint stiffness

\section{2 号機剛性および姿勢制御実験}

\section{1 姿勢一定・剛性制御実験}

拮抗駆動型手首関節 2 号機を用いて，姿勢を保持したままで の剛性制御実験を行った。

すべての ANLES に同じ巻角 0 [deg] から $500[\mathrm{deg}]$ まで 17 [deg] 刻みで与え, 姿勢を変化させず剛性だけを変化させて いく，巻角を与えたあと，関節角度を検出し一定になっている かを調べる. その後, $1[\mathrm{deg}]$ 傾くトルクを加える. トルクは遊 星歯車に取り付けられたワイヤにプーリを介して重りをぶら下 げることで付加した，最後に，関節角度を測定し各巻角での X · $\mathrm{Y} \cdot \mathrm{Z}$ 軸周りの剛性值を算出する。Fig. 14 (a) (b) (c) に実験結 果を示す.エラーバーは 5 回の繰り返し実験結果のばらつきを 示している. Fig. 14 (c) に扔いて低剛性の部分の結果がない理 由は非常に低い剛性状態では摩擦や機械的バックラッシュが相 対的に大きく影響し，測定值の再現性がないことによる，各軸
周りの剛性值はばらつきがあるものの理論值（Fig. 13 に示した ものと同じ）に沿った值となっている。

\section{2 剛性一定・姿勢制御実験}

2 号機を用いて一定の関節剛性における関節角度の制御実験 を行った. ANLES は Fig. 7 で示す番号のように手前の左から 時計回りにANLES1, 同 2, 3, 4 とする.X 軸方向に関節を傾 ける場合，ANLES3，4 番が屈曲側，ANLES1，2 番が伸展側 となる，Y 軸回転の場合は ANLES1，4 が屈曲側，ANLES2， 3 が伸展側となる。すべての ANLES に初期巻角 250 [deg] を与 えた後, 剛性一定姿勢制御の理論式（11）より求めた，関節が $0.25[\mathrm{deg}]$ 傾けるための ANLES の巻角を与える. 剛性の測定 方法は，剛性制御同様，ワイヤと重りを使用しトルクを与える. このとき，関節に対しつねに接線方向に力が加わるようにプー リを調節する。そして重りによって傾いた関角度を測定する。こ れを 50 回繰り返す. Fig. 15 (a)(b)(c)にX 軸回転の実験結果， Fig. $15(\mathrm{~d})(\mathrm{e})(\mathrm{f})$ に Y 軸回転の実験結果を示す．Fig. 15 (c)(f) 
はANLES に与えた巻角であり，Fig. 15 (a)(d) はその結果回転 した関節角度を示しており, Fig. $15(\mathrm{~b})(\mathrm{e})$ は各関節角度におい て測定した関節剛性結果を示している.エラーバーは 5 回の繰 り返し実験結果のばらつきを示している。見られるように, 関 節は $\mathrm{X}$ 軸, $\mathrm{Y}$ 軸ともにエラーバーも少なく理論值に沿った角度 まで回転した。また剛性も $\pm 0.1[\mathrm{Nm} / \mathrm{deg}]$ 程度のばらつきが見 られたが, ほぼ理論值と変わらない一定の值を示している.

\section{$5.3 \mathrm{Z}$ 軸の劣駆動型姿勢制御}

本機は主軸の回転（Z 軸回転）を行うためのモータ（モータ 5）を備えているが, モータ 5 を使用せずに 4 本の ANLES のみ である程度の Z 軸の回転が可能である。これを確認する実験を 行った，実験方法は，まず関節に剛性を与えるため ANLESに巻 角を 300 [deg] 与える. そして, ANLES1，3 と ANELS2, 4 の ような対角に配置した ANLES（Fig. 7 参照）の巻角を各 $\pm 10^{\circ}$ ずつ 24 回巻いていく（Fig. $16(\mathrm{~b}))$. Z 軸の回転角度を主軸と

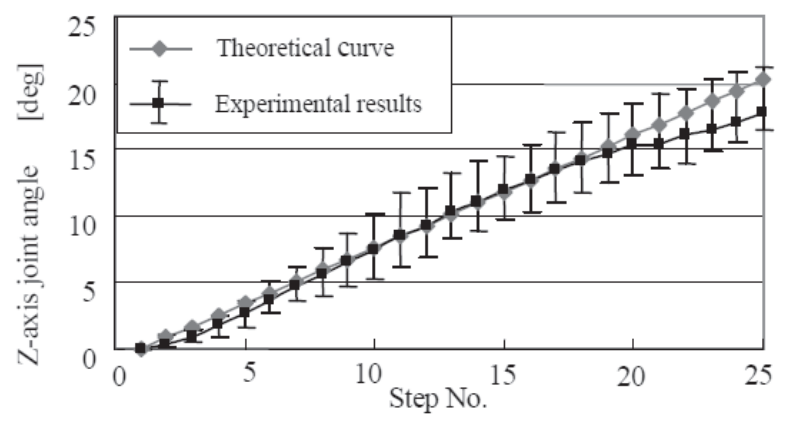

(a) Z-axis rotation angle

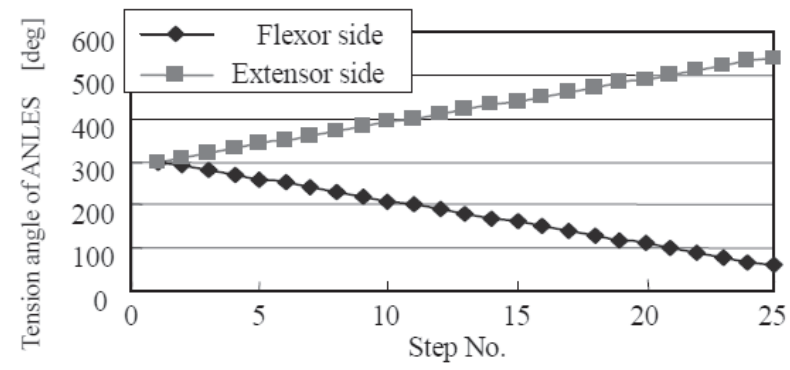

(b) Assigned torsion angle of the ANLES

Fig. 16 Z-axis rotation by 4 ANLES

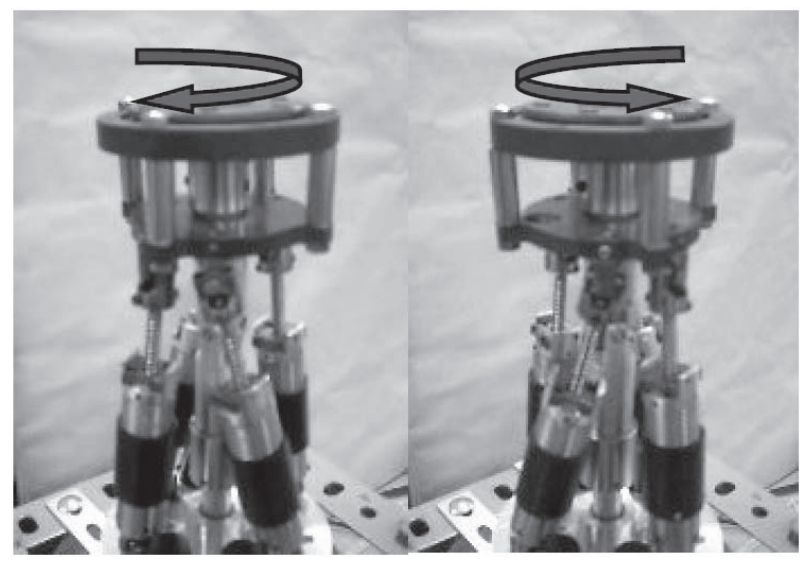

Fig. 17 Appearance of Z-axis rotation by 4 ANLES
小金澤 鋼 一

上板の差をエンコーダで計測し解析で得られた理論值と比較す る. Fig. 16 (a) に実験結果および理論值を示すままた，Fig. 17 に実験の結果 Z 軸回りに回転した様子を示す。実験結果から約 \pm 17 [deg] 回転できることが分かった（Fig.16(a)）。しかし, 姿 勢を変化させるほどに理論回転角度との誤差が大きくなってし まっている。この原因は，Z 軸を回転させる際，張力が増加す る ANLES と減少する ANLES があり，回転するに従い，張力 が減少する ANLES に存在する摩擦卜ルクの相対的割合が大き くなるからであると考えられる。しかしながら, 四つのモータ で $\mathrm{X}$ 軸 $\mathrm{Y}$ 軸の剛性と姿勢，そして Z 軸の剛性に加えて姿勢を 制御することができるので，四つの入力で六つの制御が可能な 劣駆動関節といえる.ただし, 剛性制御に関しては 3 軸が独立 していない.

\section{Viscous-ANLES}

これまで製作した ANLES はバネ・マスのみで構成されてい るため, 動的制御をした場合, 振動やオーバーシュートが生じ てしてしまう問題がある。そこで, ダンパー要素を取り入れた Viscous ANLES（以下 V-ANLES）を提案する。

\section{1 V-ANLES の構造}

本機構では，ガイドシャフトとガイドブッシュの間にシリコ ンオイルが充填されており, ガイドシャフトと伝達板, 伝達板 とガイドブッシュの間に粘性体の漏れを防ぐためにシールが施 されている (Fig. 18).

作動原理は以下のとおりである。モータからのトルク，あるい は手先からの受ける力がボールネジによって回転に変換された トルクがバネを捻る。バネはこのトルクによって巻かれ，バネ 径が減少しガイドシャフトへ巻きついていく，このとき，ガイ ドシャフトとバネの間に満たされているシリコンオイルは, 隣 り合うバネの隙間を通り抜けなければならない.したがってバ ネは粘性抵抗を受けることになりダンパーとして機能する。巻 かれたバネが戻ろうとするときにも起こるため, V-ANLES が 伸縮するときは常にダンパーとして機能する.

また，バネはガイドシャフトに巻きついていくほど弾性係数 が増加するのに対し, ダンパー係数はバネが巻きついていない バネの展開長さに比例した值をとるため減少する。したがって, 粘性は剛性が高い時に低い值になり，剛性が低い場合に大きい 值をとる。したがって V-ANLES の機構のみで効果的に振動を 抑制できると考えられる。

Fig. 19 は，製作したV-ANLES とこれを装着した 2 号機手 首関節である.V-ANLES は， 2 号機用 ANLES に比べ, 外径 が約 $4[\mathrm{~mm}]$ 大きくなったが, 全体の長さはほぼ同じサイズに

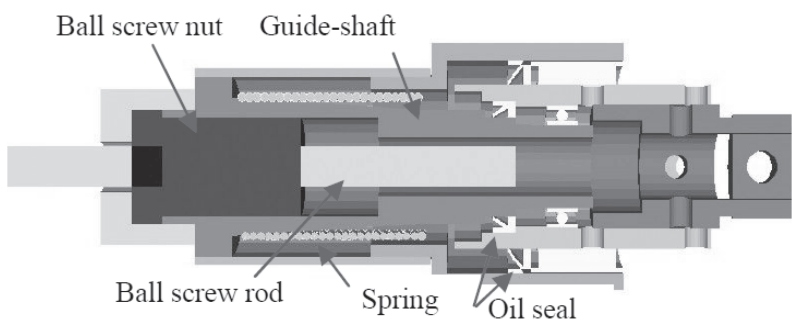

Fig. 18 Configuration of the V-ANLES 


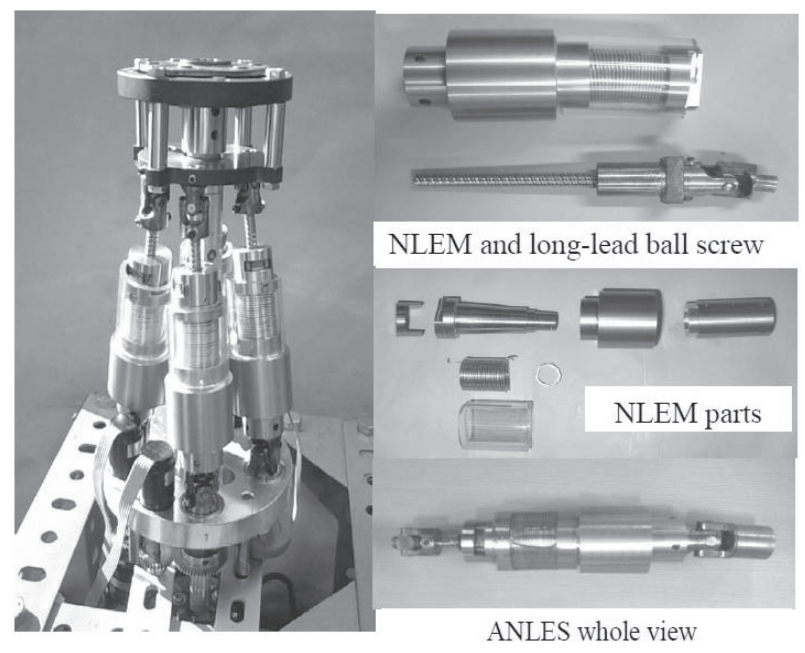

Fig. 19 Wrist joint using V-ANLES

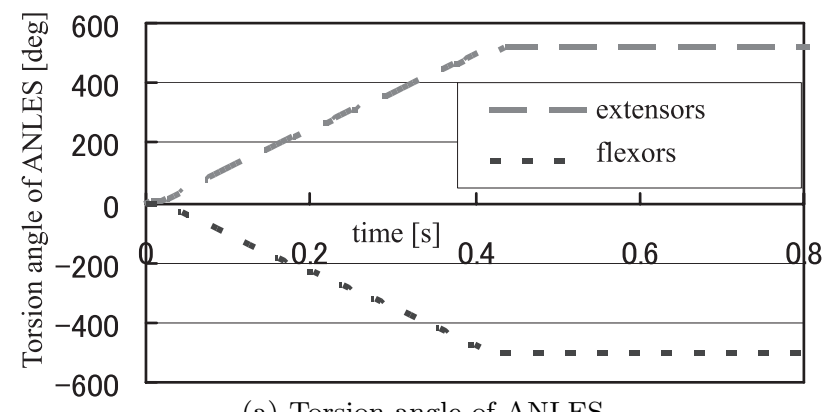

(a) Torsion angle of ANLES

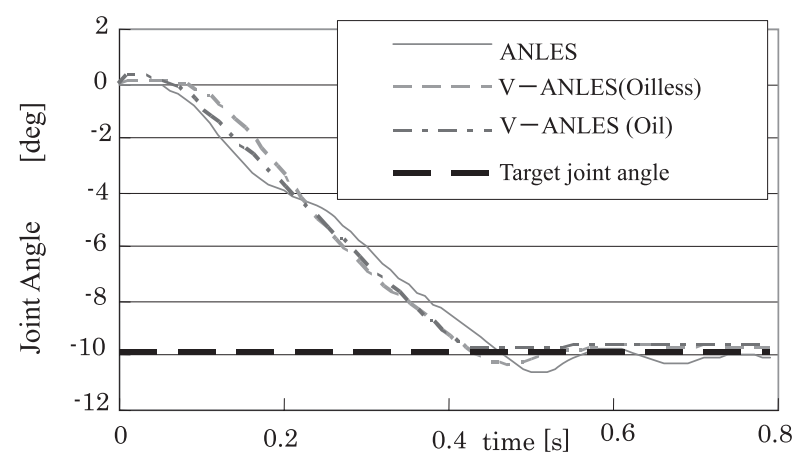

(b) Joint angle when the ANLES are twisted

Fig. 20 Stepresponse of the joint

なっており，2 号機にそのまま取り付けられるよう設計されて いる.

\section{2 V-ANLES ステップ応答実験}

V-ANLES の振動抑制効果を検証するため, ステップ応答試 験を行った。 まず，全 ANELS の巻角を $0[\mathrm{deg}]$ とした状態から, 屈曲側と伸展側に最大電圧で回転させ，目標巻角（500 [deg]） に到達後, モータを急停止させ, それによって生じる関節の振 動を計測する。V-ANLES に使用した粘性体はシリコンオイル (3,000 [CS]) である.

実験では，粘性要素を持たない従来の ANLES, V-ANLES (オイルを注入していない), V-ANLES（オイル入り）を使用し た. 実験結果を Fig. 20 に示す. Fig. 20 (a) はANLES の巻角変 化を示す. Fig. 20 (b) に関節角度の変化を示す. 従来の ANLES
の場合は, 約 1.1 [deg] のオーバーシュートが見られ整定時間は $0.7[\mathrm{~s}]$ となった. V-ANLES（Non-Oil）の場合も, ANLES 同 様のオーバーシュートが見られたが，その後の振動は見られな かった. 一方, シリコンオイルを注入した V-ANLES は, オー バーシュートはほとんど計測されずその後の振動も見られなかっ た.このことから粘性体によるダンパー効果が有効に作用して いることが分かる. しかしながら, 今回は一つの粘性体でしか 行っていないので, 今後様々な粘性体で実験し, その使用に最 適な粘性体を検討する必要がある。

\section{7. おわりに}

本稿では, ANLESをソフトアクチュエータとして用いる多 自由度関節の構造を提案した. 実証実験を行った結果, 製作し た ANLES および 3 自由度拮抗駆動型手首関節は以下の点で有 効であることが分かった。

ANLES の利点;

·非線形弾性特性を簡単かつ厳密に設計できる.

・筋肉のように腱の間に配置できるため, 手首関節のような 多自由度関節の角度・剛性制御に用いることができる.

ANLES を 4 基用いた 3 自由度手首関節の利点；

$\cdot 3$ 軸の駆動が可能である.

・独立していないが 3 軸の剛性制御が可能である.

・前腕のサイズにほぼ収納できるオールインワンの設計が可 能である.

さらに ANLES 内部にダンパー要素を取り入れたV-ANLES を考案・製作し, 駆動実験を行った結果, 振動を抑制する効果 が見られ有効性が確認できた。

また，以前まで使用していた主軸モー夕を不要にし，ANLES のみで姿勢制御する方法を提案し実験を行った。周知のとおり, 人間は筋配置が骨格に対しねじれて配置されており個々に筋を 伸縮させることで手先を広い範囲で回転させることができる機 構になっている，2 号機は人間ほどではないが, 同様にねじれ の筋配置になっており, 人間と同じ方法で $\mathrm{Z}$ 軸方向を回転させ る. 左右方向に $20[\mathrm{deg}]$ ではあるが理論值に沿って動かすこと ができた。

謝 辞 本研究の一部は, 平成 18～19 年度科学研究費補助 金（基盤研究 C）［課題番号 18560258］「非線形弾性要素を有 するアクチュエータを用いた拮抗筋駆動型関節とその剛性制御」 の研究補助金を受けてなされたものである. また, ご助言をい ただいた首都大学東京長谷和徳准教授, ならびに, 東海大学体 育学部山田洋准教授に感謝する.

\section{参 考 文 献}

[1] R. Shadmehe and M.A. Arbib: "A mathematical analysis of the force-stiffness characteristics of muscles in control of a single joint system," Biol. Cybern., vol.66, pp.463-477, 1992.

[2] P.B.C. Matthews: "The dependence of tension upon extension in the stretch reflex of the soleus muscle of the decerebrated cat," J. of Physiol., vol.147, no.3, pp.521-546, 1959.

[ 3 ] A.G. Fel'dman: "Functional tuning of the neurons system with control of movement or maintenance of a steady posture," Biofizika, vol.11, no.3, pp.498-508, 1996.

[4] J.A. Hoffer and S. Andrearsen: "Regulation of soleus muscle 
stiffness in permammiliary cats," J. of Neurophysiol, vol.45, no.2, pp.267-285, 1981.

[5] 則次俊郎：“空気圧アクチュエータ”, 日本ロボット学会誌, vol.15, no.3, pp.355-359, 1997.

[6] 岡田昌史：“人間らしい柔らかな動きと駆動機構”, 日本ロボット学会 誌, vol.17, no.6, pp.782-785, 1999.

[7] 樋野俊之, 前野隆司：“形状記憶合金を拮抗駆動配置した剛性可変小 型ロボットフィンガの開発”, 第 22 回日本ロボット学会学術講演会 予稿集 CD-ROM, 3J24, 2004.

[8] 辻内伸好, 小泉孝之, 植山博文, 横川隆一：“可変剛性行列を有する コンプライアンス制御を用いた物体把持”，Dynamics and Design Conference 2003 論文集, vol.126, 2003.
[ 9 ] 中村幸博, 谷江和雄, 前川仁：“多指ハンドによる把持物体剛性制御”, 日本機械学会論文集 (C 編), vol.59, no.566, pp.232-239, 1993.

[10] 杉山公一，大和健太郎，石井和男，金藤敬一：“導電性高分子を用い た帯状鰽型アクチュエータの開発”, ロボティクスメカトロニクス講 演会 2008 予稿集, 1A1-C02(1)-(2), 2008.

[11] 小金澤，清水：“非線形弾性システムを有するアクチュエー夕を用いた 腱駆動多自由度関節の機械式剛性制御”，日本ロボット学会誌，vol.22, no.8, pp.1043-1049, 2004.

[12] F. Lacquaniti, M. Carrozzo and N.A. Borghese: "Time-Varing Mechanical Behavior of Multijointed Arm in Man", J. of Neurophysiology, vol.69, no.5, pp.1443-1464, 1993.

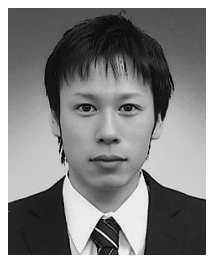

山下 裕 (Hiroshi Yamashita)

2008 年東海大学工学部機械工学科卒業, 2010 年東 海大学工学研究科機械工学専攻博士前期課程修了.

現在株式会社東芝電力システム社京浜事業所勤務. 修士論文研究において剛性可変機能を有する 3 自 由度手首関節の研究に従事. 修士 (工学).

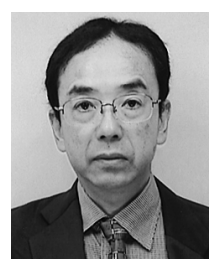

小金澤鋼一（Koichi Koganezawa）

1985 年早稲田大学大学院博士後期課程修了. 1987 年いわき明星大学講師, 1991 年東海大学講師, 2003 年教授，現在に至る。ロボットハンド，括抗型剛性 可変関節, 歩行ロボット, マルチボデイダイナミク ス, 適応制御の研究に従事. 工学博士.

(日本ロボット学会正会員) 